\title{
WANDERING IN DARKNESS: FURTHER REFLECTIONS
}

\section{ELEONORE STUMP}

Saint Louis University

\section{INTRODUCTION}

This paper, which gives me the ability to say something further about the issues involved in my book Wandering in Darkness: Narrative and the Problem of Suffering (WID), ${ }^{1}$ was made possible by a session on the book at the American Philosophical Association, Pacific Division, centred on papers by John Martin Fischer and David McNaughton, and by a workshop on the book which was held at the University of Innsbruck (organized by Georg Gasser, under the aegis of a Templeton grant on analytic theology) and which included papers by Christian Feldbacher, Georg Gasser, Adam Green, and Lukas Kraus. I am grateful to all of these philosophers for their gracious and generous comments on my book, and for their carefully reasoned, thoughtful engagement with some of the book's central ideas. I am glad of this opportunity to respond to their stimulating comments on my work, which help me to clarify some things that matter to the book's project.

In one short paper, it is not remotely possible to do justice to all the interesting issues in their comments. With regret, therefore, I have concentrated my comment on only a very few of the issues they raise, generally those that let me clarify or defend further something that strikes me as particularly important to the project as I had originally conceived it.

\footnotetext{
${ }^{1}$ Eleonore Stump, Wandering in Darkness: Narrative and the Problem of Suffering (Oxford: Oxford University Press, 2010).
} 


\section{THE COMBINATION OF METHODOLOGIES}

Christian Feldbacher worries that my attempt to combine the Franciscan mode and the Dominican mode leads not to a marriage of the two methodologies, but to something like an unequal partnership, with the Franciscan mode definitely on the underprivileged side. I appreciate this worry, because since I am myself an analytic philosopher, it is reasonable to expect that I might have leaned to the Dominican mode, instead of melding the two methodologies, as I had claimed I would do.

Feldbacher formulates the worry this way. He argues that the stories, and whatever Franciscan knowledge the stories provide, do not provide premises or support for premises in the central argument that constitutes the Thomistic theodicy at the heart of the book. ${ }^{2}$ As Feldbacher sees it, the premises of that theodicy are just what they would have been if I had not brought stories into the discussion.

On this score, Feldbacher is right. But, in my view, his being right with regard to this claim is not sufficient to validate his complaint about the book's methodology.

In discussing that methodology, I argued that only certain ways of bringing narratives into philosophy in general, and into theodicy in particular, respect the role of narratives in philosophy. On my view, to bring narratives into philosophical argument either as premises or as support for premises is to wreck the value of the narratives as sources of Franciscan knowledge. Instead, I argued, narratives should be understood as contributing to Dominican argumentation roughly in the way life experience contributes to any philosophical understanding and argumentation. That experience serves as a store of insight and intuition against the background of which we understand and evaluate, consciously or subconsciously, the merits of the premises of the philosophical argument.

By way of a concrete example, I said that the narratives examined in my book should function in a way analogous to the way in which travel to a foreign country shapes one's understanding of that country. The asit-were experience provided by a narrative will deepen one's perceptions and judgments of things, altering them in subtle and not-so-subtle ways, just as travel to a foreign country will enrich in countless inexpressible

2 This theodicy is not identical to the defence the book argues for but is central to it, as I explain in the book's first chapter. 
ways one's insights into that country. Travel to China, for example, will change a person's understandings of that country and its people in ways that he could not represent entirely or at all in propositional form. If he could represent his experience propositionally, then he could teach others by means of propositions everything he himself learned in his travel to China - and that conclusion is of course false.

So what I claimed is that, although the premises of a theodicy or defence stay the same, even after the examination of the narratives at issue, one's understanding of those premises and one's ability to evaluate them will change very substantially in consequence of the as-it-were experience provided by the stories.

I need to add, however, that this way of thinking about the Franciscan approach might have been obscured for Feldbacher because he is not entirely right about what I was trying to characterize with the label 'Franciscan'. In particular, the distinction of most importance in the book is not the distinction between knowledge that and knowledge how. Knowledge how does not in fact play a role in my methodology. The relevant distinction is between knowledge that and the knowledge of persons, which is direct, intuitive, non-propositional, and subserved by distinct brain systems designed precisely for mind-reading between conspecifics. As I was at pains to explain in the methodological section of the book, this brain system gives us a distinct kind of knowledge of persons, and I have argued that this special kind of knowledge can also be transmitted to a greater or lesser extent by stories.

\section{THE DESIRES OF THE HEART}

In WID, I also called attention to what is in my view a neglected part of the problem of evil, namely, the fact that, even when he is flourishing, a person can suffer because he has been denied the desires of his heart. In my view, this kind of suffering is redeemed when somehow, through suffering, a person receives his heart's desire but in the reshaped form which that desire has when and only when it is interwoven with a much deeper desire for union with God.

Adam Green focuses on my claim that neither heart's desires nor their loss or satisfaction is transparent. As he sees it, this claim of mine allies my position in some ways with sceptical theism. And he argues that the claim is too strong because, with regard to the desires of the heart, transparency and opacity come in degrees. He goes on to explore 
in sensitive and stimulating detail the disparate degrees of opacity for heart's desires and the alteration in that opacity produced by suffering.

In this connection, it is important to clarify that my claim about transparency does not entail that a person never knows what the desires of her heart are, or whether they have been either satisfied or lost. The claim entails only that a person's views regarding his own heart's desires and their loss or satisfaction are not infallible. ${ }^{3}$ In this regard, heart's desires are more like health than they are like pain. The state of a person's bodily health is not a matter that is invariably or infallibly known by introspection. On the other hand, as I explained in WID, '[i]t is no part of Aquinas's theodicy that suffering and its justifying benefits are opaque in every case or will always be opaque't; and the same point applies as regards the desires of the heart. My position requires maintaining only that heart's desires, and their loss or satisfaction, are not always completely transparent; it does not require maintaining that they are always completely opaque.

In addition, it is important to clarify that, on Aquinas's theodicy, sceptical theism is false: human beings are in a position to know the morally sufficient reasons that justify God in allowing suffering. The epistemic problem for human beings, on Aquinas's theodicy, is not the inscrutability of God's mind (or of general modal claims or anything else along the same lines). The problem is the inscrutability of a human heart and the complexity of a human life, which the omniscient mind of God can comprehend, but which is frequently unknown to us. The result is that, for Aquinas, although we can know what sceptical theism claims we cannot know, namely, God's general reasons for allowing suffering, we cannot know why God allowed the particular suffering he did for any particular sufferer at any particular time. The lack of knowledge premised by the defence I constructed is therefore very different from the lack of knowledge postulated by sceptical theism.

With these things clarified, I want to say only that I welcome Green's probing investigation of an issue I left untouched, namely, the degrees of transparency a heart's desires can have, and the reasons for that divergence of degree. Although I think that there is probably more confused complexity to these degrees of transparency than his account allows for, the case he mounts for supposing that suffering

\footnotetext{
${ }^{3}$ WID, pp. 12-13.

${ }^{4}$ WID, p. 409.
} 
adds considerably to the transparency of a person's desires seems to me insightful and helpful. Additional work along the same lines strikes me as certain to be significant for development of the Thomistic defense, and I hope that he will pursue the issue.

Lukas Kraus also raises some important questions regarding my treatment of the desires of the heart. Kraus objects that, on the defence argued for in the book, the heart's desires of a suffering person are in fact just given up, and not fulfilled.

Kraus holds this view at least in part because he believes that desires are individuated by their objects. Now it is certainly true that some mental states or powers are individuated by their objects. Vision, for example, can be distinguished from hearing by its objects. But the same thing is not true of desires, in my view. In particular, heart's desires are not individuated by their objects.

To see the reasons for this claim, consider a story where heart's desires play a central role.

In The Gifts of the Magi, the American author O. Henry tells a story about a wife, who had beautiful hair, and her husband, who had an heirloom pocket watch. The wife had her heart set on a pair of combs for her hair, and the husband had his heart set on a silver chain for his watch. But the two of them were very poor, and the things they wanted were very expensive. So they could not buy either the combs or the chain, and they did without these highly coveted things. At Christmas, however, in spite of their great poverty, each one of them received from the other the very marvellous, expensive, and highly desired thing. The wife received those combs from her husband, and the husband received the silver chain from his wife. And here is how the two of them found the money to buy these presents for each other. The husband sold his watch to pay for the hair combs, and the wife cut and sold her hair to pay for the silver watch chain.

O. Henry tells this story to show that the husband and the wife each got his or her heart's desire, but in a much more powerful way than either of them could have dreamt of. He finishes the story this way:

The magi ... invented the art of giving Christmas presents. Being wise, their gifts were no doubt wise ones ... And here I have lamely related to you the uneventful chronicle of two foolish children in a flat who most unwisely sacrificed for each other the greatest treasures of their house. But ... let it be said that of all who give gifts these two were the wisest. ${ }^{5}$

${ }^{5}$ O. Henry, 41 Stories (New York: New American Library. Signet Classic, 1984), p. 70. 
O. Henry takes this view of the matter because what the wife received was not only the hair combs she had so desired. Rather, she received the combs as a gift of the great, self-sacrificial love of her husband. And, mutatis mutandis, the same thing can be said about the husband. He received the silver chain he had so wanted, but he received it as a gift of the self-sacrificial love of his wife.

Now hair combs as an object of desire is very different from hair combs as the expression of a great love. Obviously, one can have hair combs which are not an expression of love. If the wife had won a sum in a lottery and bought herself the hair combs with her winnings, she would have had the hair combs, but she would not have gotten them as the expression of the great love of her husband. It is worth noticing too that, at the outset of the story, when the wife wanted the hair combs, all she had in her mind to desire was the combs themselves. As her great surprise at her Christmas present makes clear, it never entered her mind to desire the combs as a gift of great love on her husband's part. (And, mutatis mutandis, similar things can be said about the husband and the silver watch chain.)

If we had to individuate desires on the basis of their objects, as Kraus supposes, then, with regard to the O. Henry story, we would have to say that at Christmas the wife did not have the desire of her heart fulfilled, and neither did the husband. Rather, each of them failed to get his heart's desire. They may have received something else good, but they did not receive what had been their original heart's desires.

To me a conclusion of this sort seems highly counter-intuitive. On the contrary, the whole point of the O. Henry story is that a person can get her heart's desire in a way that is much deeper and better than she could ever have imagined.

So I do not think that individuating heart's desires by their objects is a good way to individuate them. In my view, this story prompts us to see that the form of any particular desire can be reshaped by the deeper desires of which it is an expression without losing its character as the desire it was. A desire can refold and still be the same desire, if the deeper desire continues to inform it.

Consider in this connection the example I used in WID involving Viktor Klemperer. When Klemperer wanted to write a book on French literature, no doubt, that desire was informed by deeper desires of his. These deeper desires might be describable in more abstract terms than the description of his desire to write a book on French literature, as Kraus 
supposes. But there will be a limit on the abstraction and generality. So, for example, Klemperer's deeper desire might have been for the fruition of his skills and talents - but it would still have been a fruition having to do with writing a book. It would not have been for the fruition of his skills and talents by means of success in hand-to-hand armed combat, for example.

In my view, because of this relation between the deeper and the more superficial heart's desire, the more superficial desire can be altered significantly without its having been given up. And that is why it is right to hold that Klemperer did get his heart's desire when he wrote his diaries, even if the diaries were not his scholarly study of French literature.

But suppose that I were wrong on this score and Kraus were right. What would follow?

The notion of a heart's desire, as I introduced it, is the notion of a desire at the centre of the web of desire, giving energy to the other desires in the web. But, I argued, for any particular person, there will also be a connected hierarchy of such desires, with some much deeper than others. So the heart's desire D1 of a person Jerome is a desire for something Jerome really wants; but a deeper heart's desire D2 is a desire that gives the energy to the more superficial desire D1. Without desire D2, Jerome would not in fact have desire D1.

Now if Kraus were right, then it could be the case that Jerome never got what would satisfy D1, but did get what would satisfy D2 instead. Klemperer's diaries might have fulfilled some deep desire of his, but they did not fulfil the heart's desire he had when he wanted to write a book on French literature.

On this way of thinking about heart's desires, my case would then have to be restated this way. Jerome's suffering because of the loss of his heart's desire D1 would be redeemed by his getting the satisfaction of his heart's desire D2. And since the satisfaction of D2 is what Jerome really wanted in wanting D1, his suffering over the loss of D1 is defeated. Although, intuitively, I want to resist this restatement, nothing about this restatement will alter the major conclusions of the defence.

Finally, what Kraus sees as two strategies on my part for dealing with suffering stemming from the desires of the heart is really only one: suffering stemming from the loss of heart's desires is redeemed by the satisfaction of heart's desires only when those desires have been reconfigured into an expression of the deepest heart's desire, which is for God. Kraus thinks that this claim makes my position collapse into the stern-minded view. But, on the stern-minded view, a person should be 
content with getting only God as the satisfaction of his heart's desires. My position, however, is better represented by the ending of the book of Job, in which Job gets intimacy with God and camels (among other things that were his heart's desires).

\section{THE NATURE OF A DEFENCE}

In this short paper, I cannot address all the stimulating and thoughtful remarks in the papers by John Martin Fischer, Georg Gasser, and David McNaughton; but they share a concern about the philosophical nature of a defence and the criteria for a successful defence, and I will focus my response to their papers largely on that issue. Gasser himself tries to answer some of the questions about the nature of a defence with the helpful notion of a worldview, taken in a technical sense. This is an insightful approach, in my view, and worth reflecting on further. But here I will confine myself just to some more general reflections on the nature of a defence and on the use of a defence to deal with the problem of evil.

I want to begin by highlighting what the goal of a defence is. There are plenty of arguments purporting to show the existence of God; but in the history of philosophy there have generally been just two kinds of argument purporting to show the non-existence of God. The most powerful of these is the argument from evil. ${ }^{6}$ So the argument from evil is constructed as an attack on theism, and a defence is a response to that attack.

It is crucial to keep this point firmly in mind because it affects greatly what we ought to expect in a defence against the argument from evil. The point of a defence against an attack is warding off the attack. It is true that, insofar as the attack of the argument from evil is warded off by a defence, theism is strengthened, because one of the best arguments against theism is undermined. But a defence against an attack on theism is still not by itself an argument for theism. The job of a defence is to turn back an attack. It is not the job of a defence to provide an argument for the existence of God, or for the truth of any of the major theistic claims about God.

Just in case this point would benefit from belabouring, consider an analogous case from biology. In 1911, Peyton Rous argued for this thesis:

\footnotetext{
${ }^{6}$ The other kind of argument attempts to show some incoherence in the standard divine attributes, such as that sometimes alleged to exist between omnipotence and perfect goodness, between omnipotence and divine free will, or between omniscience and immutability.
} 
(The Rous thesis): chicken sarcoma $\mathrm{R}$ is caused by a virus.

This thesis was rejected with derision by most of those working in the field at that time. They rebutted the Rous thesis with one or another sophisticated version of this argument:

(Attack on the Rous thesis):

(1) Chicken sarcoma R runs in families.

(2) No sarcoma that runs in families is caused by a virus.

(3) Therefore, chicken sarcoma $R$ is not caused by a virus.

On the view of the attackers, that argument was sufficient to show that the Rous thesis was false.

Now, to defend his thesis against this attack, Rous did not have to mount yet another argument to show that chicken sarcoma $\mathrm{R}$ is caused by a virus. He did not have to rerun his original experiments or dream up new experiments to try to show his thesis true in yet another way. All Rous had to do to ward off the attack was to undermine one or more of the premises in the attackers' argument or to impugn the argument's validity. In fact, Rous argued that premiss (2) is false; that is, he denied the claim that no sarcoma that runs in families is caused by a virus. To defend his thesis against this attack, it was sufficient to show that premiss false.

But notice that there is a difference between warding off the attack and supporting the original thesis. Rous might well have been successful in warding off the attack by showing the falsity of premiss (2) of the attack without its being the case that chicken sarcoma $\mathrm{R}$ is caused by a virus. A successful defence against the attack on the Rous thesis is not the same as an argument for the Rous thesis. As it happens, Rous's defence against the attack was successful; the claim that no sarcoma that runs in families is caused by a virus is not true. But the success of Rous's defence does not prove that chicken sarcoma $\mathrm{R}$ is caused by a virus. And it does not prove anything about the nature of the Rous sarcoma virus or its mode of operation either. All that Rous's defence does is show that this particular attack will not work to rule out the Rous thesis.

There may have been people for whom this approach on Rous's part to defending his thesis was disappointing. As Fischer explains his own attitude towards a defence against the argument from evil, Fischer was anticipating that a defence would give some reason for thinking theism true. Analogously, maybe partisans to the dispute over the Rous thesis were looking to Rous's defence to help them decide whether or not to believe that chicken sarcoma $\mathrm{R}$ is caused by a virus. But people who 
wanted Rous's defence against the attack on his thesis to give more evidence of the truth of that thesis were looking for that evidence in the wrong place. The evidence for the Rous thesis is not the same as a defence against an attack on the thesis. The enterprise of undermining an argument against some thesis is not the same as the enterprise of showing that thesis true.

In the same way, a successful defence against the argument from evil is not itself another argument for the existence of God. No matter how successful a defence is, it does not prove the existence of God or show the appropriateness of the standard divine attributes or anything else along these lines. It is not meant to do any of these things. A defence is the warding off of an attack on theism. Explanations of the divine attributes or arguments for the existence of God have to be found in different places.

Because this is what a defence is, the criteria for the success of a defence are a function of what the attack is. When Gertrude Stein was being wheeled in for surgery, she turned to her companion Alice and demanded, 'What is the answer?' When the startled Alice was silent, Gertrude said, 'Well, then, what is the question?' An analogous approach seems right when it comes to the nature of a successful defence. In the case of a defence against the argument from evil, the criteria for success in the answer depend on the way in which the existence of evil is used to question the existence of God.

All the varying forms of the argument from evil aim at the same conclusion, namely, 'God does not exist'. And they also all share this feature: that conclusion is supposed to follow from some facts having to do with suffering. It is something about suffering in particular - as distinct, say, from something about the divine attributes or something about the nature of goodness or something about human free will - that is supposed to demonstrate that God does not exist. What differentiates varying arguments from evil are the different ways in which they use suffering to support the conclusion that God does not exist.

Before Alvin Plantinga formulated the free-will defence, the most influential argument from evil tried to show that God does not exist on the basis of the claims that there is evil in the world and that God and evil are logically incompatible. ${ }^{7}$ No possible world that contains suffering could also be a world that contains God. This argument is relatively

${ }^{7}$ For one presentation of Plantinga's free-will defence, see Alvin Plantinga, God and Other Minds (Ithaca, NY: Cornell University Press, 1967), pp. 131-155. 
simple, in the sense that it does not need to consider any specific facts about suffering. It does not need to make any claims about the nature of particular kinds of suffering, the extent and distribution of suffering, the role of suffering in the lives of sufferers, or anything else that would require a lengthy and controversial presentation of evidence. But this form of the argument is also much stronger than it needs to be. It does not conclude just that God does not exist; it concludes that God could not exist in any world containing suffering. The very nature of God and of evil makes the co-existence of God and evil impossible.

But, as Plantinga pointed out, the claims

(1) there is an omniscient, omnipotent, and perfectly good God and

(2) there is suffering

are not by themselves logically inconsistent. At the very least, to argue on the basis of the existence of suffering to the conclusion that an omniscient, omnipotent, perfectly good God does not exist, a sound argument from evil needs to include this premiss:

(3) There is no morally sufficient reason for an omniscient, omnipotent, perfectly good God to allow suffering.

This premiss is eminently debatable, however. To defend theism against this version of the attack requires only showing that there is some possible world in which God has a morally sufficient reason for allowing that world's suffering to exist. Plantinga's justly celebrated freewill defence was directed against this form of attack.

Plantinga was generally regarded as successful in that defence. ${ }^{8}$ At the end of the initial debate over Plantinga's defence, most philosophers supposed that Plantinga had succeeded in defending theism against the particular attack at issue for him. And because he was widely taken to be successful with the free-will defence, the attack shifted and took new form.

${ }^{8}$ Fischer suggests that Plantinga's defence is more open to serious criticism than one might suppose from the admiring reception it received. Like others before him, myself included, Fischer wonders whether Plantinga's defence is in fact compatible with the claim that God is good. In my view, too, it is one thing to allow creatures free will, and another thing entirely to stand by passively while they use their free will in cruel and hateful depredations of the vulnerable and helpless. Fischer raises this point in connection with his own sparse defence, which certainly is open to criticism on this score. But whether or not Plantinga's defence is really open to attack on the grounds that it is not consistent with God's goodness, most people at the time Plantinga published his defence took the defence to be successful. 
In its new form, as the evidential argument from evil, the attack attempted to reason to the non-existence of God not on the basis of a logical incompatibility between God and suffering but rather on the basis of an incompatibility between the existence of God and facts about suffering in this world. The idea was that even if there could be a God in some world containing suffering, there could not be a God in the actual world because of some facts about the suffering in the actual world.

In this version of the attack, the crucial third premiss of the argument from evil becomes something like this:

(3') There is no morally sufficient reason for an omniscient, omnipotent, perfectly good God to allow all of the suffering that there is in the actual world.

This version of the argument from evil is a lot harder to defend against, but then it is also a lot harder to support.

The first thing to notice in this connection is that a very sparse defence against this version of the attack is actually easy to construct. Fischer proposes for our consideration a sparse defence involving a divine matrix connecting suffering to the distribution of goods in heaven, but in fact a defence even sparser than the one Fischer constructs is readily available. All one has to do is to take as a premiss the denial of the conclusion of the argument from evil and conclude to the denial of one of its premises. Bill Rowe called attention to this possibility and labelled it 'the G.E. Moore shift,', after Moore's famous defence against the sceptical attack on knowledge.

The argument of this very sparse defence goes this way:

(The G.E. Moore Shift):

(1') an omniscient, omnipotent, perfectly good God exists in the actual world.

(2') there is suffering in the actual world.

(not-3') Therefore, there is a morally sufficient reason for God to allow the suffering in the actual world.

This very sparse defence is helpful for thinking about some of the issues both McNaughton and Fischer raise. As Fischer asks, what is wrong with a sparse defence? ${ }^{10}$ Why should one think that this very

\footnotetext{
${ }^{9}$ See William Rowe, 'The Problem of Evil and Some Varieties of Atheism', American Philosophical Quarterly, 16 (1979), 335-41.

${ }^{10}$ Fischer adds that any sparse defence has to be consistent with the standard divine attributes; and he wonders in this connection whether my own defence is not inconsistent
} 
sparse defence is not successful? What are the criteria for success in the project of defence that rule out a sparse defence such as the G.E. Moore shift or that make it inadequate in some way?

The answers to these questions are implicit in William Rowe's own influential formulation of the evidential argument from evil. As Rowe constructed the evidential argument from evil in his classic article 'The Problem of Evil and Some Varieties of Atheism', there is a small ancillary argument that purports to show premiss (3') true.

On Rowe's version of the evidential argument, if it is successful, the small ancillary argument shows that the sparse defence yields a conclusion which is false. That is, if Rowe's ancillary argument is successful, then it can be shown that there is no morally sufficient reason for God to allow suffering. And if that is so, then since the sparse defence is valid, it follows that at least one of the premises in the sparse defence must be false. But it has only two. Therefore, since premiss (2') is conceded to be true by all parties to the dispute, the false premiss has to be premiss (1'), the premiss claiming that an omniscient, omnipotent, perfectly good God exists in the actual world. And so the sparse defence is shown to be unsuccessful. The conclusion of the evidential argument from evil stands: God does not exist.

In my view, any other sparse defence will be a version of the G.E. Moore shift, and it will succumb in similar ways. The matrix Fischer imagines God as using will yield a kind of morally sufficient reason for God to allow suffering, insofar as that matrix is supposed to justify God in allowing suffering. And so if Rowe's small ancillary argument for premiss (3') is successful, it will undermine not just the G.E. Moore shift but any analogous sparse defence, such as Fischer's sparse defence involving God's matrix.

But notice that the all-important premiss (3') of the evidential argument from evil is a claim about the way things are in the actual world - all the suffering in the actual world is such that it is not defeated by a morally sufficient reason justifying God in allowing it - and therefore so is its denial in a defence.

with God's goodness since it rests on the claim that God made human beings in such a way that they need healing through suffering. But here Fischer has misunderstood me. I claimed explicitly that my defence presupposes that God is not responsible for the internally alienated psychic state of human beings; and, in connection with the doctrine of original sin, I argued in detail that my account is consistent with the standard divine attributes, including omnipotence. See WID, pp. 153-155. 
There are two ways a defence can fail then. Obviously, if the defence is itself inconsistent, then it fails. Plantinga spent a great deal of effort to show that human free will is not incompatible with divine omnipotence, in order to show that the free will defence is compatible with the standard divine attributes. But a defence will also fail if it can be shown that its claims about the way the world is are false. On one basis or another, a defence against the evidential argument from evil has to make a claim about the way the world is: according to the defence, all the suffering in the world is such that it is defeated by a morally sufficient reason justifying God in allowing it. If it can be shown that this claim about the way the world is is false, the defence will have been shown to be unsuccessful, too. For a defence to be successful, then, in addition to internally consistency in the defence, it has to be the case that its crucial empirical claims are not shown to be false.

In WID, in explaining this point, I said that it would take uncontested empirical evidence to show the empirical claim of a defence false. In different ways, Fischer and McNaughton are each concerned about my criteria for success in a defence. In particular, they think that my understanding of the requirement for showing false the crucial empirical claims of a defence are too demanding. On their view, this requirement sets the bar too high for those attempting to rebut a defence. ${ }^{11}$

But here I think we have to remember the dialectic of the debate. The attack on theism by means of the argument from evil wants to show that theism is false, that God does not exist; and it claims that it can show this on the basis of facts about suffering. But then the attack needs to use only premises that are not themselves points of dispute between theism and atheism. It would make no difference to theism if it turned out, unsurprisingly enough, that a mix of theistic beliefs with beliefs rejected by theists formed an inconsistent set. Suppose, for example, that the argument from evil included the claim that all suffering causes human beings to become more internally fragmented in psyche. This is a claim that theists will certainly find incompatible with their beliefs about God. So the mix of this empirical claim and theistic belief will in fact constitute an inconsistent set, but this fact will not trouble theists, who will simply

\footnotetext{
${ }^{11}$ Similar objections are raised by Paul Draper in his review of WID in Notre Dame Philosophical Reviews (July 27, 2011) < http://ndpr.nd.edu/news/24772-wanderingin-darkness-narrative-and-the-problem-of-suffering $>$ [accessed 08/09/2012], and by William Hasker, 'Light in the Darkness? Reflections on Eleonore Stump's Theodicy', Faith and Philosophy, 28 (2011), 432-50.
} 
reject the empirical claim about the effects of suffering in human lives. So if the argument from evil is to have a chance of being successful, it cannot itself rest on controverted empirical claims rejected by theists.

Or, to put the same point in a slightly different way, if the argument from evil relies on empirical claims rejected by theists, then the argument shows not that something about suffering is incompatible with the existence of God, but that something about suffering and a controverted empirical claim are incompatible with the existence of God. And in that case it is easy to save belief in the existence of God: just reject the controverted empirical claim. Since the theist already rejects this empirical claim, the lesson that he must reject it to preserve belief in the existence of God will not trouble him.

And that is why I claimed that a defence that is internally consistent and not in violation of uncontested empirical evidence is successful.

Is there then uncontested empirical evidence to show that the empirical claims of the defence in WID are false? This question brings me back to Fischer's sparse defence and Rowe's small ancillary argument that purports to refute every version of a sparse defence. What is Rowe's support for the crucial premiss (3')? Unless that support is successful, it seems that a sparse defence, such as the G.E. Moore shift, should be sufficient to rebut the evidential argument from evil, in the form Rowe gave it.

Rowe's support for premiss ( $\left.3^{\prime}\right)$ is actually very simple. It comes essentially to this:

Rowe's ancillary argument for premiss (3'):

Premiss (P) It appears that there is no morally sufficient reason for God's allowing the suffering in the actual world.

(3') Therefore, there is no morally sufficient reason for an omniscient, omnipotent, perfectly good God to allow the suffering in the actual world.

A large literature has arisen around this ancillary argument for premiss (3'), and two different ways of undermining it have emerged.

On one of these ways, one can call in question the support (P) gives to (3'). It can happen, for different kinds of reason, that appearances are a very unreliable guide to reality. For example, if our perceptual or cognitive capacities are insufficient to detect the thing in question, then with regard to that thing the way things appear to our perception or cognition is not a reliable guide to the way things are. Sceptical theism is one version of this kind of response to Rowe's argument. 
But a second way to respond to Rowe's argument is to try to find a morally sufficient reason that God could have to allow suffering. If one can give a morally sufficient reason that could justify God's allowing the suffering in the actual world, then the appearance that there is no such reason is undermined. (And if one can also explain why that morally sufficient reason would be difficult to detect, then in addition there is good reason for supposing that appearances are not an adequate guide to the way things are.)

It was widely thought that the attack on theism posed by Rowe's evidential argument from evil was irrefutable by this second way of constructing a defence against it. Like Rowe himself, promoters of this version of the argument from evil often took some real or imagined heart-breaking example of suffering and then, by way of challenge, asked explicitly or implicitly how anyone could be so shameless as to try to give a reason that could justify God's allowing that evil.

And that is the version of the attack on theism by means of an argument from evil that I was responding to. The defence I constructed was tailored to the sort of attack mounted by Rowe and others in the formulation of the evidential argument from evil that they gave.

The philosophical or left-brain part (as Paul Draper ${ }^{12}$ and Fischer have called it) of the defence I constructed, shows the epistemology, metaphysics, ethics, psychology, and theology of a world within which there is a morally sufficient reason for God to allow suffering of the sort found in the actual world. This part of the defence also shows why that reason is hard to see. So, without supporting sceptical theism, the leftbrain part of the defence undermines Rowe's argument from evil in both the ways in which it is vulnerable.

On the other hand, the narrative or right-brain part of the defence gives detailed examples of the particular ways in which that morally sufficient reason might operate in the particular life histories of individual people. The stories prompt intuitions about the details and the particulars, and they also provide insight into why appearances are a bad guide to reality in such cases.

${ }^{12}$ See Paul Draper's review of WID in Notre Dame Philosophical Reviews, op. cit. Draper's review, which is the toughest review the book has received, is also in my view the deepest and most insightful of all the responses to the book. His philosophical acuity and his great personal integrity are both in evidence in his review, and I admire him greatly on both scores. 
And here it is worth saying a word about the question Fischer raises: why bother with defence at all? Why not try to give a theodicy? For that matter, one might ask, why not simply say that my defence is a theodicy? The usual reason given for preferring a defence to a theodicy is that a defence does not claim to give actual reasons for God to allow evil and that there is no reason to think finite human beings could know the mind of God. Some versions of sceptical theism are expressions of this or an analogous attitude. But, in the defence I constructed, there is no reliance on sceptical theism. On the contrary, the defence is not shy about attributing to God particular reasons for allowing suffering. The defence attributes a particular set of reasons for allowing suffering to God and claims God's revelation as warrant for doing so. So why shouldn't this defence simply be taken as a theodicy?

The answer lies in the very richness of the defence, to which Fischer calls attention. As part of the defence, I adopted a particular set of views in metaphysics, epistemology, ethics, and moral psychology, together with a particular set of positions in psychology, and a particular Thomistic theology. All of this is part of the defence. If I were to claim that this is a theodicy rather than a defence, I would also have to claim that each of these views and positions is true; and then I would be responsible for giving some arguments for each of them. At that point, my book would have become a library. But because my project is only a defence, I do not have to claim that each of the philosophical, psychological, or theological positions I adopt is true. I have to make only the much more limited claim that each of them could be true in a world very much like ours as regards human beings and suffering.

So one way to think of a defence such as mine is as a conditional theodicy. If the actual world is the way I have described the possible world of the defence as regards metaphysics, epistemology, ethics, psychology, and theology, then my account is a theodicy, which rebuts the attack of the evidential argument from evil by giving the morally sufficient reasons God actually has for allowing the suffering found in the actual world.

And this brings me to the version of the argument from evil in which Fischer and McNaughton express interest. It is yet another attack on theism, and it has a form different from Rowe's evidential argument. This version of the attack on theism does not depend crucially on the claim that there is no morally sufficient reason for God to allow evil, or on support for that claim from the appearances of the world. Instead, 
this attack relies on a comparison of theism and naturalism with regard to plausibility or probability or simplicity or epistemic surprise or something else along these lines. This attack is a matter of considering naturalism and theism as rival candidates for a grand unifying theory of everything, and then judging that naturalism is the better theory of the two because it gives a more plausible or more probable or more simple or less surprising explanation of the actual world, given that there is suffering in the world. ${ }^{13}$

I myself do not see why anyone would suppose that theism should turn to a theodicy or a defence for help with this attack. Evaluation of comparisons between grand unified theories of everything, and criteria for such evaluation, belong to the province of philosophy of science and epistemology, not to the realm of either theodicy or defence, as far as I can see. But whatever the area of philosophy may be that has global theory comparison as part of its domain, evaluation of competing grand unified theories (GUTs) of everything is not going to be an easy job.

Pretty clearly, comparing naturalism and theism as rival GUTs will be a much harder job than comparing competing theories of the nature of light, say, or theories of the disease-causing agent for bovine spongiform encephalitis. ${ }^{14}$ The explananda for naturalism considered as a GUT range from physics to music, from neuroscience to consciousness, from sociology to morality, from developmental psychology to awe at beauty and self-sacrificial love. It is not an easy matter to say which GUT is a better explanation across the board of all these things. Or, as Gasser

${ }^{13}$ In his review of WID, Draper makes it clear that he too thinks the argument from evil should be understood and formulated in this way. William Hasker's claims that a defence has to be such that, given theism, we have no strong or good reason to think its claims false fall into the same family of views. (See Hasker, 'Light in the Darkness?') That is because, as Gasser's paper helps to make clear, what one takes to be a good or strong reason is a function of all the other things one believes.

${ }^{14}$ Bovine spongiform encephalitis (BSE), or mad cow disease, which is a variant of a disease found in human beings and other species, is now believed to be caused by a prion, a protein only, that is, a molecule without DNA or RNA. But when Stanley Prusiner coined the term 'prion' in 1982, most researchers assumed that disease-causing agents had to be caused by some living organism and so had to be caused by something which included either DNA or RNA. The idea that a simple protein could be a diseasecausing agent greatly complicated the picture of disease then widely shared, and so Prusiner's claim that BSE is caused by a prion was initially met with great scepticism and severe criticism. It was widely thought, in the 1980s, that his experiments were defective and that he had derived wrong conclusions from them. But Prusiner was right, and in 1997 he won the Nobel prize for his work on prions. 
might put it, it is not so easy to give an evaluative comparison of highly differing worldviews.

In his own formulation of this version of the attack on theism, Paul Draper bases his argument from evil on the claim that, in the face of suffering in the world, naturalism is a simpler theory of the world than theism. ${ }^{15}$ But consider the problems facing Draper in trying to make a comparison of this sort.

To begin with, what makes a theory simple? Is a theory simple in virtue of having only a small number of laws? In virtue of postulating only a small number of entities? In virtue of postulating only entities and laws that are themselves simple? And what makes an entity or a law simple? In addition, even if we could find a good set of criteria for simplicity in theories, what makes one theory simpler than another? If one theory postulates more laws but fewer entities than another theory that postulates fewer laws but more entities, which is the simpler theory? If one theory postulates many laws and many entities but leaves nothing unexplained, is it a simpler theory than one which has fewer laws and fewer entities but also has a number of unexplained brute facts?

Even if we agreed on all these issues, how are we to weigh simplicity against other virtues of a theory? A theory could be simple but dead wrong, because the phenomena it is attempting to describe are themselves complicated. Earlier competing theories of the nature of light were very simple by comparison with quantum mechanics, for example. ${ }^{16}$ According to contemporary descriptions of quantum mechanics, quantum mechanics tells us that light is both a wave and a particle, that a particle can be both decayed and not decayed, that a cat can be both alive and dead, and that particles at opposite ends of the universe can be entangled, so that they operate in tandem even when there is no possibility of a signal passing between them. Surely, this is a very complicated theory of light, much less simple than its earlier competitors. But, according to contemporary physics, the complicated theory is right, and the earlier, simpler theories are false.

Very roughly analogous things can be said as regards probability, plausibility, and epistemic surprise. What makes one theory more

${ }^{15}$ I am grateful to Draper for sharing with me in advance material from his forthcoming book on this subject, which will be impressive, judging from what I have seen of it. See also his review of WID.

${ }^{16} \mathrm{I}$ am focusing here just on the example involving light, but see footnote 14 for a similar example involving disease-causing agents. 
plausible or less surprising than another will depend on very many things, difficult to evaluate. And, in addition, there will be great subjective variability. What one person finds plausible or surprising depends on the other things that person believes. Few biologically literate people now find it surprising or implausible to suppose that a virus can cause a cancer that runs in families. We understand now that a virus can hijack the genome of an organism, and that some genomes are more vulnerable than others to the onslaught of particular viruses. But a hundred years ago, when we knew very little about the nature of genes or the operation of viruses, the idea that a virus could cause a sarcoma which runs in families seemed wildly implausible, outrageously surprising, to most biologists. It seemed so improbable a notion that no one bothered even to try to replicate the experiments Rous reported in 1911. It was not until 1966 that Rous won the Nobel prize for his discoveries - which seemed so implausible and surprising in 1911.

So, for all these reasons, I do not think it will be an easy matter to show that, with naturalism and theism taken as grand unified theories of everything, naturalism is to be preferred to theism. Or, to put it in Gasser's terms, I do not think it will be easy to weigh worldviews and give a good argument that the naturalistic one is in every way preferable to the theistic one.

So this latest version of the attack on theism, with its formulation of the argument from evil depending on global theory comparison, does not look particularly promising to me. But whatever its merits may be, it is not the form of the attack my defence is meant to defend against. I am grateful to Gasser, Fischer, and McNaughton for their thoughtful comments and questions which helped me to clarify further than I had originally done what the project of my defence is.

\section{THE HARDEST CASES}

Finally, McNaughton and I agree about which cases are the hardest for the defence in WID, and I want to finish by saying one more word about them. These cases were a special focus for me in WID. There I said that,

By his choices and actions, it is possible for one creature to destroy entirely any office of love he had or might have had with another. The entire system of creation, as Aquinas sees it, is predicated on this sort of possibility, even for God. There cannot be a union of love between two persons, even if one of them is divine, unless there are two persons. 
Something whose will is completely determined by another cannot be united with that other; there is only one will in such a case, not the two needed for union. For God, ... to be willing to take another person, with an independent will, as the desire of the heart is to accept the possibility of being rejected instead of being loved. ${ }^{17}$

On these views, if Paula has her daughter Julia as the desire of her heart, then it is entirely possible for Paula to lose her heart's desire irrevocably. How, then, could it be possible for God nonetheless to provide for Paula her heart's desire, even in a refolded form, as the defence in WID requires? As McNaughton sees it, there is no good answer to this question.

The problem with McNaughton's position is its tacit presupposition that a person who rejects love is the same as she would be if she accepted love. But this presupposition is mistaken, in my view, and it makes a great difference to the assessment of the satisfaction of a heart's desire for that person.

On the kind of example McNaughton has in mind, Julia is the heart's desire of her mother Paula, but Julia rejects Paula's love as well as God's and goes to the bad (as McNaughton puts it). For the sake of adding concreteness to the example and thereby aiding intuition, suppose that Julia's going to the bad includes Julia's being addicted to drugs and supporting her habit by theft and drug-dealing. In the beginning of Julia's choices to continue her drug habit by dealing and stealing, Paula will do all she can for Julia; and she will hope against hope that Julia can be redeemed and restored to her mother's love. But after years of struggle, during which Paula suffers one pain, one defeat, after another because of Julia's continual betrayal of her mother's love, Paula will come to understand that Julia is what her choices have made her: a selfish thief, a callous drug-dealer, an irredeemable drug addict. At that point, Paula will no longer want Julia to live with her. At that point, no one will want Julia to live with her, because no one will want the kinds of depredations Julia invariably brings with her.

Even in these circumstances, at this point, it is still possible for Paula (or for anyone else) to love Julia; but, because of what Julia has become, the office of love will change from what it might have been. For example, Paula's desire to have Julia as part of her daily life (which is the form a desire for union with Julia would have had in Paula) will change in Paula to become only compassion for Julia held at a distance. And the

${ }^{17}$ WID, p. 474. 
desire for Julia's good will change into a desire to give whatever care Julia will still accept.

But these changes in Paula's desires of love for Julia will not leave Paula in a state of heart-brokenness if Paula has woven her desire for Julia into a deepest heart's desire for God, as I argued in WID. Interwoven in that way, Paula's love for Julia will be situated within Paula's participation in union with God, shared with other persons who are also united to God in love. The loneliness Julia has willed for herself cannot take away the joy of that shared union for Paula. On the contrary, Julia's choices have changed her from the dear companion she might have been for Paula to a hard-edged destructive creature, cold-hearted to others, focused only on feeding her habit.

Seen in this way, Julia is not someone who rejects Paula; she is someone who excludes herself from the joy in which Paula's life is lived. And so what might have been an active desire on Paula's part to have Julia as an intimate part of her life will become an encompassing compassion, content to offer as much care as possible to a person who has walled herself off from love. In this shape, Paula's heart's desire for Julia can be satisfied.

Even in these hardest cases, then, a heart's desire can refold and be satisfied in that refolded form. If Julia rejects the love of Paula and of God, it is still open to Paula to love Julia as she can from within the joy of union with God. In that condition, even her grief over Julia's rejection of love can be encompassed in the fulfilment of Paula's deepest heart's desire to love God and be loved by him. In the face of Julia's rejection, Paula's heart's desire for Julia, like God's own desire for those of his creatures who reject him, has to refold from a desire for realized union to a desire for giving compassion and care. But, refolded in this way, it is also capable of fulfilment from within the joy of the shared union of love with God.

So I share McNaughton's sensitive judgment that such cases are the hardest ones for theodicy and defence. But, in my view, the (real or imagined) details of such cases point to a resolution of those cases, too. As I argued in WID, ultimately, one person's darkness cannot take away another person's joy. But that is what would happen if Julia's willed loneliness left Paula permanently heartbroken.

No one has put this point better than C.S. Lewis, in my view. In addressing this same issue (though under a different guise), C.S. Lewis has one of the redeemed in heaven say to her husband, who will not accept her love or God's, 
Frank, ... listen to reason. Did you think joy was created to live always ... defenceless against those who would rather be miserable than have their self-will crossed? ... You made yourself really wretched. That you can still do. But you can no longer communicate your wretchedness.... Our light can swallow up your darkness: but your darkness cannot now infect our light. ${ }^{18}$

Lewis has his own character in the story comment doubtingly on this speech, 'Is it really tolerable that she should be untouched by his misery, even his self-made misery?' In response, his teacher in the story says,

That sounds very merciful but see what lurks behind it. ... The demand of the loveless and the self-imprisoned that they should be allowed to blackmail the universe: till they consent to be happy (on their own terms) no one else shall taste joy: that theirs should be the final power ... I know it has a grand sound to say ye'll accept no salvation which leaves even one creature in the dark outside. But watch that sophistry or ye'll make a Dog in a Manger the tyrant of the universe. ${ }^{19}$

\section{CONCLUSION}

With that final response, let me conclude by saying one more time how much I appreciate all the stimulating comments of all these papers. I am grateful for the thoughtfulness and insights which their authors have brought to bear on Wandering in Darkness and on the important questions about suffering that are of great concern to all of us. ${ }^{20}$

\footnotetext{
${ }^{18}$ C. S. Lewis, The Great Divorce (San Francisco, CA: Harper, 2001), pp. 132-133.

${ }^{19}$ C. S. Lewis, The Great Divorce, pp. 135-146.

${ }^{20}$ In addition to the authors to whose papers I am responding here, others also need to be thanked. I am particularly grateful to conversations with Paul Draper and the participants in the 2011 St. Thomas Summer Seminar in Philosophy of Religion and Philosophical Theology, organized by Michael Rota and Dean Zimmerman, under the aegis of a grant from the John Templeton Foundation. I am also grateful for the comments and questions from participants in the APA Pacific Division session held on WID and from participants in the workshop on WID held at the University of Innsbruck and organized by Georg Gasser.
} 